\title{
PRELIMINARY EVALUATION OF HUMAN HEALTH RISKS FROM INGESTION OF ORGANOTIN CONTAMINED SEAFOOD IN BRAZIL
}

\author{
Marcos Antonio Fernandez ${ }^{{ }^{*}}$, Aricelso Maia Limaverde ${ }^{2}$, Arthur de Lemos Scofield ${ }^{2}$ \\ \& Angela de Luca Rebello Wagener ${ }^{2}$ \\ ${ }^{1}$ Universidade do Estado do Rio de Janeiro - UERJ \\ Departamento de Oceanografia \\ (Rua São Francisco Xavier 524, 20550-013, sala 4018E, Maracanã, RJ, Brasil) \\ ${ }^{2}$ Pontifica Universidade Católica do Rio de Janeiro - PUC-Rio \\ Departamento de Química \\ (Rua Marquês de São Vicente, 225, 22453-900, Gávea, RJ, Brasil) \\ *Corresponding author: hallfz@uerj.br
}

The toxic effects of tributyltin (TBT) and triphenyltin (TPT), used as biocides in antifouling paints, as defensives fungicides or present in industrial effluents, on aquatic organisms are well known (Fent, 1996) and has led many countries to control their application as antifoulants since the eighties (Champ, 2000; Hoch, 2001). A global ban on the application of these compounds as biocides was scheduled by IMO to begin in January, 2003. The convention has, however, not yet been enforced and the use of the compounds continues in several countries. The biological effects of organotin compounds have been described for many places on the Brazilian coast, always related to centers of maritime activity such as harbors, shipyards and marinas, and relatively high concentrations of organotins have been detected in sediments and organisms in the two most important areas of maritime activity in Brazil (Fernandez et al., 2005; Castro et al., 2004; Camillo Jr et al., 2004; Godoi et al., 2003). This situation shows the need to assess possible health risks for human populations, arising from ingestion of contamined seafood.

This study employed a padronized risk evaluation methodology, the Risk Quotient, by which the few available data on organotins in seafood were tested to generate the RQ's for specific scenarios. The edible mussell Perna perna is, together with the neogastropod Stramonita haemastoma, the only species in which organotins have been determined in Brazil. Chemical speciation of organotins (TBT and their derivatives DBT and MBT and TPT and derivatives DPT and MPT) employed acid extraction with tropolone and derivatization by the Grignard reaction, detection having been made using GC-PFPD. Analytical quality control used Certified Reference Material NIES-11 from Japan (Limaverde, 2002). Two scenarios were tested, one for the general population and the other for populations of fishermen, with their different ingestion rates, as well as two other concentrations, the highest (Guanabara Bay) and the lowest (Arraial do Cabo) concentrations reported from mussell populations off the Rio de Janeiro state coast
(Limaverde, 2002). Values for other parameters of the RQ model were similar to those employed by the other studies presented, with the exception of adult body weight. An ADI value for TBT $\left(3.0 \times 10^{-4} \mathrm{mg} \mathrm{TBT} / \mathrm{kg}\right.$ body weight/day) is that recomended by the United States Environmental Protection Agency (EPA, 1997). Seafood ingestion rates for Brazilian populations were derived from a recent work (Scott \& Ross, 1998). As no data were available for fishermen populations, an intermediate value was derived from the studies made in the United States of America and Taiwan. Mussells were considered as whole seafood, as no other data on organotin concentrations in Brazil were available. The data thus generated were compared to those from the studies undertaken in the USA (Cardwell et al., 1999) and in Taiwan (Chien et al., 2002). These studies used the same methodology and very extensive databases, differently from the present study, as animals of a single species were taken from just two locations. Because of these severe limitations this study can only be considered a preliminary experiment in risk evaluation. expression

The Risk Quotient model is derived from the

$$
\mathrm{RQ}=\frac{\mathrm{EF} \times \mathrm{ED}_{\text {tot }} \times \text { Ring } \times \mathrm{C} \times 10^{-3}}{\text { Dref } \times \text { BWad } \times \text { ETmed }}
$$
following:

Where the parameter values are the

$$
\begin{aligned}
& \mathrm{EF} \quad=\text { Exposure Frequency }=350 \mathrm{~d} / \mathrm{y} \\
& \mathrm{ED}_{\mathrm{tot}}=\text { Exposure Duration }=70 \mathrm{y} \\
& \mathrm{Ring} \quad=\text { Ingestion Rate }=\mathrm{g} / \mathrm{d} \\
& \mathrm{C} \quad=\text { Concentration TBT (wet weight) } \mu \mathrm{g} / \mathrm{g} \\
& \mathrm{Dref} \quad=\text { Reference Dose }=3 \times 10^{-4} \mathrm{mg} / \mathrm{kg} / \mathrm{d} \\
& \mathrm{BWad}=\text { Body weight, adult }=70 \mathrm{~kg} \\
& \mathrm{ETmed}=\text { Exposition Time, mean }=365 \mathrm{~d} / \mathrm{y} \mathrm{x} 70 \mathrm{y} \\
& \text { The values calculated for RQ and the most } \\
& \text { important parameters in the model are shown in Table }
\end{aligned}
$$


1. Values for the general population in Brazil ( 0.027 to 0.226 , depending on concentrations) are greater than those for the USA ( $4.0 \times 10^{-3}$ for mollusk consumption only; for other data see Cardwell et al., 1999) but smaller than those for Taiwan (0.902 when mollusk consumption and mean concentrations were considered). For fishermen populations, the values calculated for Brazil (1.005) are close to the risk limit (1.0). This value is higher than those reported for the USA ( 0.095 in the worst scenario, that is with mollusk consumption only and highest reported concentrations of mollusks) but again lower than those reported for Taiwan (1.602 for the highest consumption rate and mean concentrations; for the worst scenario, this value attains 3.713).

The low observed values of RQ in the USA were due basically to the lower TBT concentrations in seafood, as compared with those for Taiwan and Brazil. This observation is supported by the results of another recent study on a global scale (Keithly et al., 1999 ), in which low values for RQ were observed in Korea (0.180), France (0.087), USA (0.036, mean), Singapore (0.048), Sweden (0.041), Australia (0.021), Canada (0.018) and England (0.011). However, the reported concentrations of TBT in bivalves in this study are very low (3.3 to $115 \mathrm{ng} / \mathrm{g} \mathrm{ww}$ ) as compared to those reported in other studies, as quoted. Also the calculations for this study were made only on the means for general populations and not on those for specific populations. That is why these data have not been included in Table 1.

Anyway, it seems that organotin health risks are under control in the developed countries, thanks to the control exercised over their use (see Champ, 2000, for a review on this subject). On the other hand, under particular conditions such as those described in the study of Chien et al, 2002, and in the present study, organotin derived health risks might still be very high in developing countries where their use is not controlled, and where the new organotin (but not biocide) free antifouling are beginning to be employed at the same time (Basheer et al., 2002).

Considering the severe limitations of the available database, the findings of this study may only suggest the possibility of health risks derived from organotins in seafood for some local human populations in Brazil, and point to the urgent need to increase knowledge both on populational seafood ingestion rates and also on pollutant concentrations in seafood. Only in this way can consistent risk evaluation scenarios be addressed in Brazil in the near future.

Table 1. Values for calculated RQ'S and most important parameters utilised in the calculations.

\begin{tabular}{|c|c|c|c|c|c|}
\hline & Target study & $\operatorname{Ring}(g / d)$ & $\mathrm{C} \mu \mathrm{g} / \mathrm{g}$ (Wet weight) & BWad & RQ \\
\hline \multirow[t]{5}{*}{$\begin{array}{l}\text { Chien et al., } 2002 \\
\text { Taiwan }\end{array}$} & $\begin{array}{l}\text { General } \\
\text { population }\end{array}$ & 18.6 & $\begin{array}{c}0.132 \\
\text { (mean organotin conc.) }\end{array}$ & 65 & 0.121 \\
\hline & & 139.0 & $\begin{array}{c}0.132 \\
\text { (mean organotin conc.) }\end{array}$ & 65 & 0.902 \\
\hline & Fishermen & 94.1 & $\begin{array}{c}0.132 \\
\text { (mean organotin conc.) }\end{array}$ & 65 & 0.611 \\
\hline & & 250 & $\begin{array}{c}0.132 \\
\text { (mean organotin conc.) }\end{array}$ & 65 & 1.623 \\
\hline & & 250 & $\begin{array}{c}0.302 \\
\text { (worst scenario) }\end{array}$ & 65 & 3.713 \\
\hline \multirow[t]{2}{*}{$\begin{array}{l}\text { Cardwell et al., } \\
\text { 1999, EUA }\end{array}$} & $\begin{array}{l}\text { General } \\
\text { Population }\end{array}$ & 20.1 & $\begin{array}{c}3.1 \times 10^{-3} \\
\text { (mean organotin conc.) }\end{array}$ & 70 & $4.0 \times 10^{-3}$ \\
\hline & Fishermen & 170 & $\begin{array}{c}12.2 \times 10^{-3} \\
\text { (worst scenario) }\end{array}$ & 70 & 0.095 \\
\hline \multirow[t]{4}{*}{ This Study } & General & 44.9 & $13.0 \times 10^{-3}$ & 70 & 0.027 \\
\hline & & 44.9 & $110 \times 10^{-3}$ & 70 & 0.226 \\
\hline & $\begin{array}{l}\text { Fishermen } \\
\text { (estimate) }\end{array}$ & 200 & $13.0 \times 10^{-3}$ & 70 & 0.119 \\
\hline & & 200 & $110 \times 10^{-3}$ & 70 & 1.005 \\
\hline
\end{tabular}




\section{ACKNOWLEDGEMENT}

We whish to thank Faperj (M.A. Fernandez) and $\mathrm{CNPq}$ (A.M. Limaverde) for funding part of this research project, and an anonimous reviewer for his/her valuable comments.

\section{REFERENCES}

Basheer, C.; Tan, K. S. \& Lee, H. K. 2002. Organotin and Irgarol-1051 contamination in Singapore coastal waters. Mar. Pollut. Bull., 44:697-703.

Castro, I. B.; Meirelles, C. A.; Matthews-Cascón, H. \& Fernandez, M. A. 2004. Thais (Stramonita) rustica (Lamarck, 1822)(Mollusca: Gastropoda: Thaididae), bioindicator of contamination by organotin compounds in the coast of Natal city, Rio Grande do Norte state in northeast Brazil. Braz. J. Oceanogr., 52(2):43-47.

Camillo, E.; Quadros, J.; Castro, I. B. \& Fernandez, M. A. 2004. Imposex in Thais rustica (Mollusca: Neogastropoda) (Lamarck, 1822) as an indicator of organotin compound pollution in Maceió coast (Northeastern Brazil). Braz. J. Oceanogr., 52(2):101-105.

Cardwell, R. D; Keithly, J. C. \& Simmonds, J. 1999. Tributyltin in U.S. market-bought seafood and assessment of human risks. Human Ecol. Risk Assess., 5(2):317-335.

Champ, M. A. 2000. A Review of organotin regulatory strategies, pending actions, related costs and benefits. Sci. total Environment, 258:21-71.

Chien, L. C.; Hung, T. C; Choang, K. Y.; Yeh, C. Y.; Meng, P. J.; Shieh, M. J. \& Han, B. C., 2002. Daily intake of TBT, $\mathrm{Cu}, \mathrm{Zn}, \mathrm{Cd}$ and As for fishermen in Taiwan. Sci. Tot. Env., 285: 177-185.
EPA, 1997. Toxicological review: tributyltin oxide (CAS No 56-35-9) in support of summary information on the Integrated Risk Information System (IRIS). Washington DC. United States Environmental Protection Agency.

Fent, K. 1996. Ecotoxicology of organotin compounds. Crit. Rev. Toxicol., 26, 1-117.

Fernandez M. A., Wagener A. L. R., Limaverde A. M. Scofield A. L., Pinheiro, F. M. \& Rodrigues, E. 2005. Imposex and surface sediment speciation: a combined approach to evaluate organotin contamination in Guanabara bay, Rio de Janeiro, Brazil. Mar. Env. Res., 59:435-452.

Godoi, A. F. L; Montone, R. C. \& Santiago-Silva, M. 2003. Determination of butyltin compounds in surface sediments from the São Paulo state coast (Brazil) by gaschromatography-pulsed flame photometric detection. J. Chrom. A., 985: 205-210.

Hoch, M. 2001. Organotin compounds in the environment an overview. Appl. Geochem., 16: 719-743.

Keithly, J. C; Cardwell, R. D. \& Henderson, D. G., 1999. Tributyltin in seafood from Asia, Australia, Europe and North America. Hum. Ecol. Risk Assess., 5(2): 337-354.

Scott, P. C. \& Ross, L. G. 1998. O Potencial da Mitilicultura na Baía de Sepetiba. Panorama da Aquicultura, set/out 1998, p. 13-19 (in Portuguese).

\section{Sources of Unpublished Material}

Limaverde, A. M. 2002. A study on organotin compounds speciation in Thais (Stramonita) haemastoma by GCPFPD aiming to evaluate its bioindication potential. $\mathrm{PhD}$ Thesis. Rio de Janeiro Ponticificial University, Rio de Janeiro (in Portuguese).

(Manuscript received 03 April 2005; revised 16 June 2005; accepted 12 August 2005) 